\title{
Análise do protocolo diagnóstico do mormo em quatro propriedades brasileiras
}

Carla Macedo Amorim ${ }^{[a]}$, Alline de Paula Reis ${ }^{[b]}$

[a] Jóquei Clube Hipódromo da Lagoinha, Goiânia, GO, Brasil
${ }^{[b]}$ École nationale vétérinaire d'Alfort (EnvA), Maisons-Alfort, Val-de-Marne, França

*Autor correspondente

e-mail: carlacheval@hotmail.com

\section{Resumo}

Doença bacteriana dos equídeos cujo agente etiológico é a Burkholderia mallei, o diagnóstico do mormo baseia-se em testes sorológicos como o Western Blotting (WB), Fixação de Complemento (FC), ELISA e isolamento da bactéria através de cultura, testes bioquímicos e moleculares, os quais podem ter seus resultados influenciados por fatores como tempo e temperatura de incubação, qualidade do sistema complemento, antígeno, características do agente e da população testada. 0 objetivo deste trabalho foi analisar o protocolo diagnóstico utilizado em quatro propriedades (A, B, C, D) localizadas em quatro estados brasileiros entre os anos de 2009 e 2016. Os animais testados foram equídeos de idades variadas, ambos os sexos, em número de 131, 33, 671 e 476 indivíduos alojados nas propriedades A, B, C e D, respectivamente. Identificou-se os tipos de testes utilizados para triagem e confirmação da doença, número de coletas de todo rebanho, os prazos para entrega dos resultados e intervalo entre testes, bem como a porcentagem de testes com resultados contraditórios. Em todas as propriedades os procedimentos se basearam em duas baterias de exames em todo o rebanho, com resultados negativos consecutivos para que tivessem o trânsito de animais liberado. 0 protocolo utilizado em A, B e D foi FC como teste de triagem do rebanho e WB como teste confirmatório para os animais que obtivessem resultados diferentes de negativo, com o intervalo entre a primeira e a segunda coleta variando entre 45 e 60 dias. Na propriedade C, foram utilizados três tipos de protocolos: primeiramente, durante as nove primeiras coletas (do rebanho), foi utilizado o FC como teste definitivo para a confirmação da doença; 397 dias após a interdição da propriedade (durante a décima, décima primeira, décima segunda e décima terceira coletas), foi alterado o protocolo para WB como teste único e definitivo de todos os animais; e para a décima quarta, décima quinta, décima sexta, décima sétima, décima oitava e décima nona coletas foram utilizados ambos os testes associados a exemplo 
das demais propriedades. Em média, o intervalo entre a coleta e emissão de resultados foi de 15, 25, 23 e 27 dias e os intervalos entre coletas foram de 58,53, 107 e 65 dias nas propriedades A, B, C e D, respectivamente. Foram realizadas duas coletas em todo rebanho em A, seis em B, dezenove em $\mathrm{C}$ e seis em D. Além disso, observou-se variação de resultados em um mesmo indivíduo, sendo que 22 (16,7\%), 21 (63,6\%), 49 (10,29 \%) e 26 cavalos (3,87\%) foram positivos ao FC e posteriormente negativos ao WB nas propriedades A, B, D e C, respectivamente; quatro (3,05\%), 17 (51,5\%), 20 (4,2\%) e 17 animais (2,53\%) inicialmente positivos ao $\mathrm{FC}$ e posteriormente negativos no mesmo exame nas propriedades A, B, D e C, respectivamente; e 11 (8,39\%), três $(9,0 \%)$, um $(0,2 \%)$ e cinco $(0,74 \%)$ inicialmente positivos para o FC e posteriormente inconclusivos ao mesmo teste nas propriedades A, B, D e C, respectivamente. Podemos concluir que houve variação entre os protocolos utilizados para diagnóstico do mormo nas diferentes propriedades quanto ao número de coletas do rebanho, o tipo de teste realizado para triagem e confirmação, prazos (tempo decorrido entre coletas e entre coletas e a entrega dos resultados), além da discrepância de resultados para um mesmo indivíduo entre a primeira coleta e as seguintes. Novos estudos devem ser realizados a fim de se determinar se esta variação ocorre devido à sensibilidade/especificidade dos testes em nosso rebanho ou devido a problemas técnicos no processamento dos mesmos. Esforços devem ser empregados para se conhecer o comportamento epidemiológico da doença mormo no Brasil e para padronizar a metodologia do trabalho para erradicação e controle da doença.

Palavras-chave: Equídeos. Validação. Sorologia. 